\begin{tabular}{|c|c|c|}
\hline & Int.J.Curr.Microbiol.App.Sci (2016) 5(11): $842-853$ & \\
\hline & International Journal of Current Microbiology and Applied Sciences & morken - \\
\hline & ISSN: 2319-7706 Volume 5 Number 11 (2016) pp. 842-853 & \\
\hline $\begin{array}{l}\text { EXCELLENT } \\
\text { PUBLISHERS }\end{array}$ & & (1) \\
\hline
\end{tabular}

Original Research Article

http://dx.doi.org/10.20546/ijcmas.2016.511.096

\title{
Sustainable Solid Waste Management: Isolation of Cellulolytic Microorganisms from Dumpsites in Lagos, Southwest Nigeria
}

\author{
Ojo-Omoniyi $^{1 *}$, Olusola Abayomi, Okwa $^{2}$, Omolade Olayinka, Junaid ${ }^{1}$, \\ Iswat Olaide and Ikuoye ${ }^{1}$, Abosede Oyebola \\ ${ }^{1}$ Department of Microbiology, Lagos State University, P.M.B. 0001 LASU Post Office, \\ Lagos-Nigeria \\ ${ }^{2}$ Department of Zoology and Environmental Biology, Lagos State University, P.M.B. 0001 \\ LASU Post office, Lagos-Nigeria \\ *Corresponding author
}

\section{Keywords}

Solid Waste

Management,

Microorganisms

from Dumpsites.

\section{Article Info}

Accepted:

26 September 2016

Available Online:

10 October 2016

\section{A B S T R A C T}

This research was to carry out an environmental surveillance for cellulosedegrading microorganisms present in wastes dumpsites in Lagos, southwest Nigeria. Solid waste has become a heavy burden to both government and citizens in developing countries all over the world due to increase in population. The presence of cellulolytic microorganisms and their potential to degrade the complex polymer; cellulose into simple sugars like glucose under optimum environmental conditions were also evaluated. Soil and leachate samples were collected $(0-10 \mathrm{~cm}$ depth $)$ from three dumpsites in Lagos following aseptic procedures and the microbial species were isolated using Nutrient agar and Potato-dextrose agar media respectively. A total of 34 microorganisms were isolated from the three different sampling locations in Lagos. The cellulase-producing microbial species were characterized following conventional and standard microbiological methods. They were then screened for cellulase activity using the Cellulose Congo-Red plate technique. The diameters of clear zone of inhibition were measured in millimeters $(\mathrm{mm})$. All isolates were cellulase producers, with Bacillus licheniformis having $42.5 \%$ occurrence, as well as the highest cellulase activity and hydrolytic value (34mm and 8.5 respectively) among the bacterial species while Aspergillus $s p .(40.0 \%$ occurrence) had the highest cellulase activity $(63 \mathrm{~mm})$ and hydrolytic value (15.8) among the fungal species. This result suggested that these microorganisms utilized the available sources of cellulose present in wastes both for growth, biomass production and biodegradative processes. Consequently, the introduction of these microorganisms into waste recycling processes will enhance the sustainable solid waste management practices for megacities as well as the quality of public health in developing economies.

\section{Introduction}

Municipal solid wastes is composed of 40$50 \%$ cellulose, 9-12\% hemicelluloses 10$15 \%$ lignin on a dry weight basis (Rani and
Nand, 2000; Gautam et al., 2010). These waste materials could be turned from liabilities into assets. Microorganisms which 
utilize cellulosic materials for their carbon and energy source could be exploited for the conversion of these wastes into products that are beneficial to man (Belewu and Banjo, 1999; Banjo and Kuboye, 2000; Belewu and Afolabi, 2000).

Microorganisms perform their metabolic processes rapidly with remarkable specificity under ambient conditions catalyzed by their diverse enzymesmediated reactions. The introduction of microbial enzymes as an alternative to harsh chemical technologies has led to intensive exploration of natural microbial biodiversity to discover microbial enzymes with possible application in waste recycling under appropriate conditions (Gautam et al., 2010).

Cellulase is the key enzyme for the conversion of cellulosic materials into simple sugars which can serve as feed-stock for the production of different chemicals and fuels via anaerobic fermentation (Ryu and Mandels, 1980). Cellulolytic enzymes play an important role in natural biodegradation processes in which plant ligno-cellulosic materials are effectively degraded by cellulolytic fungi, bacteria, Actinomycetes and protozoa.

Many fungi capable of degrading cellulose synthesize large quantities of extracellular cellulases that are more efficient in depolymerising the cellulose substrate. Cellulases produced by bacteria, appear to be bound to the cell wall and are unable to hydrolyze native ligno-cellulose preparation to any significant extent.

Examples of bacteria and fungi capable of producing cellulase include Trichoderma sp., Humicola sp., Penicillium sp., Aspergillus sp., Pseudomonas sp., Bacillus sp., Staphylococcus sp., Cellulomonas sp., etc., (Gautam et al., 2010).
The objectives of the current study is to isolate, characterize and identify the native microbial population in waste dump sites in Lagos as well as to evaluate the potentials of these microorganisms isolated for cellulase production.

\section{Materials and Methods}

\section{Collection of soil samples and leachates}

Soil and leachate samples were collected from three dumpsites under the control of Lagos State Waste Management Authority (LAWMA), Lagos state. The dumpsites were; Hotel Soluos -Igando Landfill site in Alimosho Local Government Area, Olushosun Landfill site in Kosofe Local Government Area and Ibeshe -Ikorodu in Ikorodu Local Government Area. These dumpsites are labeled A, B and C respectively.

The soil and leachate samples were collected in the morning from each dumpsite between 10-11am. Soil samples were collected aseptically from a depth of $0-20 \mathrm{~cm}$ with sterile soil auger. The temperature of the refuse dump in each location was monitored with a thermometer and the mean temperature range was recorded for eachdumpsite. The soil samples were labeled A, B and C while the leachate samples were labeled AL, BL, and CL respectively. The samples were transported to the laboratory immediately for microbiological analysis.

\section{Isolation of Microorganisms from Soil Samples and Leachates}

The collected soil and leachate samples were serially diluted until $10^{-6}$ dilutions was achieved. However, $1 \mathrm{ml}$ sample was taken from diluent $10^{-4}$ and $10^{-6}$ and this was inoculated on sterile Nutrient agar media (NA) plates and Potato dextrose agar (PDA) 
plates in duplicates using spread plate technique and this was followed by incubation at $30 \pm 2{ }^{\circ} \mathrm{C}$ for $24-48$ hours for the Nutrient agar plates and the PDA plates were incubated at $30 \pm 2{ }^{\circ} \mathrm{Cleft}$ for $4-8$ days. After incubation, the plates were examined for growth and the numbers of colonies were counted to give the viable count of microorganisms in the samples. Representative colonies were purified by repeated streaking on NA and PDA plates, the isolated bacteria and fungi were identified on the basis of their colonial morphology, microscopic morphology and biochemical tests. The identified strains were maintained on PDA and NA slants at low temperature $\left(4^{0} \mathrm{C}\right)$ (Gautam et al., 2012).

\section{Biochemical Characterization}

Biochemical tests were performed in order to identify the isolates using Gram staining, catalase test, citrate test, indole test, Urease test, oxidase test, MetyhlRed-VogesProskauer test, gelatinase test, starch hydrolysis test and sugar fermentation.

\section{Microscopic examination of fungal cells}

Each fungus isolated was sub-cultured on Potato dextrose agar (PDA) and characterized. Thee spore head, color of mycelium, characteristics of hyphae were observed. Pieces of young mycelium from the periphery of each culture were cut with sterile razor blade and placed on clean glass slides. Cut section were flamed briefly to melt the agar and then stained with lacto phenol cotton blue, cover slips was then placed over each slide and examined under the microscope by the $\mathrm{x} 40$ objective lens (Cheesbrough, 2004).

\section{Screening for Cellulolytic Activity}

Confirmation of cellulose degrading ability of the bacteria and fungi isolates was performed by inoculating their pure cultures in the centerof Cellulose Congo Red agar with the following composition: $\mathrm{KH}_{2} \mathrm{PO}_{4}$, $\mathrm{MgSO}_{4}$, Cellulose, agar, gelatin, and distilled water at $\mathrm{pH}$ 6.8-7.2. Isolates showing discoloration of Congo-Red were taken as positive cellulose- degrading bacteria and the diameter of the clearance zone was measured with the aid of a calibrated meter rule and recorded. Cellulose-degrading potential of the positive isolates was also qualitatively estimated by calculating hydrolysis capacity ( $\mathrm{HC})$, that is, the ratio of diameter of the clear zone and colony (Lu et al., 2005).

\section{Results and Discussion}

The standard and conventional methods for microbiological analysis revealed through morphological and biochemical tests that bacterial isolates were of eight different (8) genera (Table 1).

The colonial and microscopic characterization of the fungal isolates showed that they belong to the genera; Penicillium, Aspergillus and Trichoderma (Table 2). Pure culture of fungal isolates are presented in Figure 1.

The percentage of occurrence of the bacterial and fungal isolates from the three dumpsites studied were recorded with Bacillus sp. having the highest value $(42.5 \%)$ among the bacterial isolates while Aspergillus sp. ranked the highest among the fungal isolates $(40.0 \%)$ (Tables 3 and 4).

Bacillus licheniformis showed the highest zone of clearance $(34 \mathrm{~mm})$ and hydrolytic value (8.5) while Streptococcus sp. showed the least values ( $7 \mathrm{~mm}$ and 2.3 respectively) (Table 5). However, the fungal isolates with the least clearance zone and hydrolytic value was Penicillium sp. $\quad(39 \mathrm{~mm}$ and 7.8 
respectively) while Aspergillus sp. (63mm and 15.8 respectively) had the highest cellulase-producing potential and hydrolytic value (Table 6).

This present research revealed the presence of various bacterial and fungal species known to be associated with cellulose degradation in wastes dumpsites. A total of 34 microorganisms were isolated. However, 19 of these isolates were bacterial species and 15 fungal species, these species belonged to the genera: Bacillus, Corynebacterium, Pseudomonas, Staphylococcus, Streptococcus, Enterobacter, Aeromonas, Klebsiella, Trichoderma, Aspergillus, and Penicillium. All isolates reported in this study have also been reported to be associated with waste and waste biodegradation (Obire et al., 2002).

The temperature of soil samples from all dumpsites ranged between $30^{\circ} \mathrm{C}$ and $34^{\circ} \mathrm{C}$ and this falls within the mesophilic temperature $\left(20-45^{\circ} \mathrm{C}\right)$. The temperature range obtained in this study is within the range reported by $\mathrm{Lu}$ et al., (2005) who showed that 15 cellulose degrading bacteria isolated from vegetable wastes were within mesophilic temperature range. All isolates were screened for cellulase activity by using the Cellulose Congo Red plate technique. The result showed that all tested isolates were cellulase producers but their ability to degrade cellulose differs from organism to organism, and this was indicated by the diameter of the clearance zone presented by each isolate on the cellulose Congo red plates (Lu et al., 2005).

In the bacterial group, Bacillus species had the highest occurrence $(42.5 \%)$ in all dumpsites compared to other isolates because they are indigenous to soil environment and have the ability to survive harsh environmental conditions. This observation agrees with the findings of Holt
(1994) who reported that the abundance of strains of Bacillus genus in refuse samples is not surprising since this ubiquitous genus is known to include cellulolytic species and are commonly found in soil and plant litter as well as compost where they play major role in biodegradation and bio-conversion of macromolecules. In addition, Beg and Gupta (2003) reported them to be the most important source of several enzymes aside from $B$. cereus and B. anthracis. They have been considered safe to humans.

The cellulolytic bacteria isolates encountered in this study showed a hydrolytic capacity value (HC) between 2.3 and 8.5 and this is similar to that reported by $\mathrm{Lu}$ et al., (2005) for mesophilic cellulase degrading bacteria. Fungal isolates presented a higher $\mathrm{HC}$ value than the bacteria with value between 7.8 and 15.8.

Maximum cellulase activity was also observed in Bacillus species with diameter of clearance zone ranging between $20 \mathrm{~mm}$ $34 \mathrm{~mm}$ in respect to other bacteria isolates. Among these, Bacillus licheniformis presented the largest zone $(34 \mathrm{~mm})$, followed by Bacillus sphaericus $(27 \mathrm{~mm})$ and Bacillus subtilis $(26 \mathrm{~mm})$. This finding is in line with the report of Das et al., (2010) who isolated 8 bacteria strains from cow dung samples and observed maximum cellulase activity among Bacillus species as well as Pseudomonas, Klebsiella, Staphylococcus, Coryne-bacterium, Aeromonas and Enterobacter were found to be moderate cellulase producers with diameter of clearance zone ranging between $18 \mathrm{~mm}$ and $25 \mathrm{~mm}$ while Streptococcus sp. showed the lowest value between $7 \mathrm{~mm}$ and $9 \mathrm{~mm}$.

Cellulolytic fungal isolates encountered in this study showed a higher diameter of clearance zone than the bacteria isolates with Aspergillus sp. having the highest value $(63 \mathrm{~mm})$, followed by Trichoderma $\mathrm{sp}$. 
(58mm) and Penicillium sp. (48mm). This agrees with the findings of Kang et al., (1999) who reported that Aspergillus strains have the ability to produce $\beta$-glucosidase with significantly higher yields than Trichoderma species and they have a number of characteristics which makes them the ideal organisms for industrial applications such as fermentation capabilities, ability to assimilate various organic substrates and suppress development of other organisms and high sporulation capacity.

Gautam et al., (2010) studied on the isolation and screening of cellulolytic fungi from municipal solid waste. Out of 20 fungal culture isolates from environmental sources including 8 different zones, 16 fungi were found to possess cellulose degrading ability. Result obtained during this study clearly suggested that cellulase activity of Aspergillus fumigatus and Trichoderma sp. were found relatively towards the higher side and A. niger, A. flavus, A. nidulans, Alternaria sp., and Penicillium sp. showed moderate range activity while Fusarium sp., Humicola and Torulasp., showed low cellulase activity.

This result suggested that fungi are better cellulase producers than the bacterial species and this was in accordance with the findings of Guatam et al., (2009) who discovered that many fungi capable of degrading cellulose synthesize large quantities of extracellular cellulases that are more efficient in depolymerizing the cellulose substrate unlike cellulases produced by bacteria which appear to be bound to the cell wall and are unable to hydrolyze native lignocelluloses preparation to any extent.
In conclusion, the conversion of cellulolytic biomass by microorganism is a potential sustainable approach to develop novel bioprocesses and products. Microbial cellulases are now commercially produced by several industries globally and are widely used in food, animal feed, fuel, paper industry and also various chemical industries. Cellulases are important in waste recycling processes for efficient waste to energy systems.

This study showed that waste dumpsites are source of cellulolytic microorganisms. Among all the isolates, Bacillus species, Aspergillus sp., and Trichoderma sp. have shown high cellulase activity compared to other isolates. These organisms are recommended as source of cellulases which may be harnessed for industrial production of the enzyme as well as management of solid wastes containing cellulose.

The result of this investigation is useful to industries that use cellulases (textile, laundry, detergents, pulp and paper industries) since microorganisms are cheap natural resource and also environmental agencies that are concerned with solid wastes management.

Environmental agencies can take advantage of the result of this investigation and then invest in further studies which could lead to the isolation and characterization of specific high yielding bacterial and fungal strains found in the local soil environments. This will go a long way in reducing the cost of management of solid wastes. However, further studies needed to be carried out to determine quantitatively the catalytic activity of the cellulases produced by each of these organisms. 
Table.1 Cultural morphology and biochemical characteristics of bacterial isolates

\begin{tabular}{|c|c|c|c|c|c|c|c|c|c|c|c|c|c|c|c|c|}
\hline $\begin{array}{l}\text { Isolate } \\
\text { Code }\end{array}$ & Colour & ఏ & 离 $\frac{\overrightarrow{0}}{8}$ & 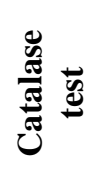 & 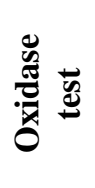 & 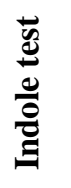 & 苑 & 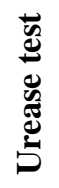 & 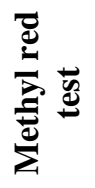 & 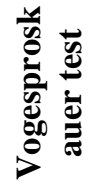 & 竞 & 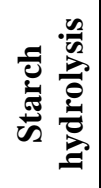 & 苟 & 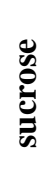 & 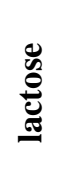 & Probable Identity \\
\hline Aa $10^{-6}$ & $\begin{array}{c}\text { Cream- } \\
\text { white }\end{array}$ & + & cocci & + & + & - & - & - & - & + & + & - & + & + & + & Staphylococcus albus \\
\hline Aa $10^{-4}$ & $\begin{array}{c}\text { Brown- } \\
\text { green }\end{array}$ & + & cocci & - & - & + & + & + & - & - & + & + & + & + & + & Streptococcus \\
\hline $\mathrm{Ba} 10^{-6}$ & cream & + & rods & + & + & - & + & - & - & + & + & + & + & + & + & Bacillus subtilis \\
\hline $\mathrm{Ba} 10^{-4}$ & cream & + & rods & + & - & - & + & - & - & - & + & + & + & + & - & Bacillus licheniformis \\
\hline $\mathrm{Ca} 10^{-6}$ & cream & + & rods & + & + & - & - & + & - & + & + & - & + & - & - & Bacillus sphaericus \\
\hline $\mathrm{Ca} 10^{-4}$ & Green & - & rods & + & + & - & - & - & - & - & + & - & + & + & - & $\begin{array}{l}\text { Pseudomonas } \\
\text { cepaciae }\end{array}$ \\
\hline $\mathrm{AL}^{-4} 0^{-4} \mathrm{~A}$ & Cream & - & rods & + & - & - & + & - & - & + & + & - & + & + & + & Klebsiellaaerogenes \\
\hline $\mathrm{AL}^{-4} 0^{-4} \mathrm{~B}$ & Cream & - & rods & + & + & _ & + & _ & - & + & + & _ & + & - & - & Bacillus coagulans \\
\hline $\mathrm{AL}^{-4} 0^{-4} \mathrm{C}$ & White & - & rods & + & - & - & + & - & - & + & - & - & + & + & + & $\begin{array}{l}\text { Enterobacter } \\
\text { aerogenes }\end{array}$ \\
\hline $\mathrm{AL}^{-6} 0^{-6} \mathrm{~A}$ & cream & - & rods & + & - & _ & + & - & - & + & + & + & + & + & - & Bacillus licheniformis \\
\hline $\mathrm{AL}^{-6} 0^{-6} \mathrm{~B}$ & Cream & + & rods & + & - & - & + & - & - & + & + & + & + & + & - & Bacillus licheniformis \\
\hline $\begin{array}{l}\mathrm{AL}_{1} 10^{-6} \\
\mathrm{C}\end{array}$ & Cream & - & rods & + & + & + & - & - & - & + & + & + & + & - & + & Aeromonas \\
\hline $\mathrm{BL} 10^{-4} \mathrm{~A}$ & Cream & + & $\begin{array}{l}\text { Coccoid } \\
\text { rods }\end{array}$ & + & + & - & - & - & - & + & + & + & + & + & + & $\begin{array}{l}\text { Corynebacterium } \\
\text { stratum }\end{array}$ \\
\hline $\mathrm{BL}^{-4} 0^{-4} \mathrm{~B}$ & Yellow & + & cocci & + & - & - & - & + & - & + & - & - & + & + & + & Staphylococcus aerus \\
\hline $\mathrm{BL}^{-6} 0^{-6} \mathrm{~A}$ & Cream & + & Rods & + & + & - & + & - & - & + & + & + & + & + & + & Bacillus substilis \\
\hline $\mathrm{BL}^{10} 0^{-6} \mathrm{~B}$ & Cream & + & rods & + & - & - & + & - & - & - & + & + & + & + & - & Bacillus licheniformis \\
\hline $\mathrm{CL} 10^{-4} \mathrm{~A}$ & Cream & & & + & - & - & + & - & - & - & + & - & + & + & + & Klebsiellaaerogenes \\
\hline $\mathrm{CL}_{10}^{-4} \mathrm{~B}$ & Green & - & rods & + & + & - & + & - & - & - & + & - & + & - & - & $\begin{array}{l}\text { Pseudomonas } \\
\text { aeruginosa }\end{array}$ \\
\hline $\mathrm{CL}_{10}{ }^{-6}$ & Cream & + & cocci & - & - & + & + & + & - & - & + & + & + & + & + & Streptococcus \\
\hline
\end{tabular}


Table. 2 Colonial and microscopic characteristics of fungal isolates

\begin{tabular}{|c|c|c|}
\hline Fungal Isolates & $\begin{array}{l}\text { Macro- culture (colonial } \\
\text { characteristics) }\end{array}$ & $\begin{array}{l}\text { Microscopy (morphological } \\
\text { features) }\end{array}$ \\
\hline Penicillium species & $\begin{array}{l}\text { Blue green or ash flaky } \\
\text { colonies }\end{array}$ & $\begin{array}{l}\text { Septate hyphae, branched } \\
\text { conidiophores, a brush like } \\
\text { colonial head }\end{array}$ \\
\hline Aspergillus niger & $\begin{array}{l}\text { Large black head ( thick black } \\
\text { colonies) }\end{array}$ & $\begin{array}{l}\text { Septate hyphae, non- septate } \\
\text { conidiophores, mop- like conidial } \\
\text { head }\end{array}$ \\
\hline Trichoderma species & White colonies & $\begin{array}{l}\text { Branched conidiophores and aerial } \\
\text { hyphae }\end{array}$ \\
\hline
\end{tabular}

Table.3 Occcurrence of bacterial isolates in dumpsites

\begin{tabular}{|l|c|c|c|c|c|c|c|c|}
\hline Isolated organism & $\mathbf{A}$ & $\mathbf{A L}$ & $\mathbf{B}$ & $\mathbf{B L}$ & $\mathbf{C}$ & $\mathbf{C L}$ & $\begin{array}{c}\text { Total } \\
\text { number of } \\
\text { isolates }\end{array}$ & $\begin{array}{c}\text { \% of } \\
\text { occurrence }\end{array}$ \\
\hline Staphylococcus & 1 & $\mathrm{ND}$ & $\mathrm{ND}$ & 1 & $\mathrm{ND}$ & $\mathrm{ND}$ & 2 & 10.5 \\
Streptococcus & 1 & $\mathrm{ND}$ & $\mathrm{ND}$ & $\mathrm{ND}$ & $\mathrm{ND}$ & 1 & 2 & 10.5 \\
Bacillus & $\mathrm{ND}$ & 3 & 2 & 2 & 1 & ND & 8 & 42.5 \\
Enterobacter & ND & 1 & ND & ND & ND & ND & 1 & 5.2 \\
Aeromonas & ND & 1 & ND & ND & ND & ND & 1 & 5.2 \\
Corynebacterium & ND & ND & ND & 1 & ND & ND & 1 & 5.2 \\
Pseudomonas & ND & ND & ND & ND & 1 & 1 & 2 & 10.5 \\
Klebsiella & ND & 1 & ND & ND & ND & 1 & 2 & 10.5 \\
\hline
\end{tabular}

KEYS:

$\%=$ Percentage

$\mathrm{ND}=$ Not determined

$\mathrm{B}=$ Olushosun soil sample

$\mathrm{C}=$ Ibeshe soil sample
A $=$ Hotel soluos soil sample

$\mathrm{AL}=$ Hotel soluos leachate sample

$\mathrm{BL}=$ Olushosun leachate sample

$\mathrm{CL}=$ Ibeshe leachate sample

Table.4 Occcurrence of fungal isolates in dumpsites

\begin{tabular}{|c|c|c|c|c|c|c|c|c|}
\hline $\begin{array}{l}\text { Isolated } \\
\text { organism }\end{array}$ & A & $\mathbf{A L}$ & B & BL & C & CL & $\begin{array}{l}\text { TOTAL } \\
\text { NO. } \\
\text { ISOLATES }\end{array}$ & $\begin{array}{l}\text { \% of } \\
\text { OCCURRENCE }\end{array}$ \\
\hline Penicillium & $\mathrm{ND}$ & 1 & 1 & 1 & ND & 1 & 4 & 26.7 \\
\hline Aspergillus & 1 & ND & 2 & 1 & 1 & 1 & 6 & 40.0 \\
\hline Trichoderma & 1 & ND & 1 & 1 & 2 & ND & 5 & 33.3 \\
\hline
\end{tabular}

Keys:

$\%=$ Percentage

$\mathrm{ND}=$ Not determined

$\mathrm{B}=$ Olushosun soil sample

$\mathrm{C}=$ Ibeshe soil sample
A $=$ Hotel soluos soil sample

$\mathrm{AL}=$ Hotel soluos leachate sample

$\mathrm{BL}=$ Olushosun leachate sample

$\mathrm{CL}=$ Ibeshe leachate sample 
Table.5 Mean diameter of clearance zone and hydrolytic capacity value for cellulolytic bacteria

\begin{tabular}{|c|c|c|}
\hline Isolate code & $\begin{array}{c}\text { Mean diameter of } \\
\text { clearance zone (mm) }\end{array}$ & Hydrolytic capacity \\
\hline $\mathrm{Aa} 10^{-6}$ & 18 & 6.0 \\
$\mathrm{Aa} 10^{-4}$ & 7 & 2.3 \\
$\mathrm{Ba} 10^{-6}$ & 24 & 8.0 \\
$\mathrm{Ba} 10^{-4}$ & 24 & 8.0 \\
$\mathrm{Ca} 10^{-6}$ & 27 & 6.8 \\
$\mathrm{Ca} 10^{-4}$ & 18 & 3.6 \\
$\mathrm{AL} 10^{-4} \mathrm{~A}$ & 18 & 4.5 \\
$\mathrm{AL} 10^{-4} \mathrm{~B}$ & 20 & 6.7 \\
$\mathrm{AL} 10^{-4} \mathrm{C}$ & 25 & 8.3 \\
$\mathrm{AL} 10^{-6} \mathrm{~A}$ & 31 & 7.8 \\
$\mathrm{AL} 10^{-6} \mathrm{~B}$ & 34 & 8.5 \\
$\mathrm{AL} 10^{-6} \mathrm{C}$ & 24 & 4.5 \\
$\mathrm{BL} 10^{-4} \mathrm{~A}$ & 25 & 6.3 \\
$\mathrm{BL} 10^{-4} \mathrm{~B}$ & 23 & 5.8 \\
$\mathrm{BL} 10^{-6} \mathrm{~A}$ & 26 & 6.5 \\
$\mathrm{BL} 10^{-6} \mathrm{~B}$ & 33 & 8.3 \\
$\mathrm{CL} 10^{-4} \mathrm{~A}$ & 20 & 4.0 \\
$\mathrm{CL} 10^{-4} \mathrm{~B}$ & 16 & 5.3 \\
$\mathrm{CL} 10^{-6}$ & 9 & 2.3 \\
\hline
\end{tabular}

KEY:

$\mathrm{A}=$ Hotel soluos soil sample

$\mathrm{AL}=$ Hotel soluos leachate sample

$\mathrm{B}=$ Olushosun soil sample

$\mathrm{BL}=$ Olushosun leachate sample

$\mathrm{C}=$ Ibeshe soil sample

$\mathrm{CL}=$ Ibeshe leachate sample

Table.6 Mean diameter of clearance zone and hydrolytic capacity value for cellulolytic fungi

\begin{tabular}{|c|c|c|}
\hline Isolates code & $\begin{array}{c}\text { Diameter of zone of } \\
\text { Clearing(mm) }\end{array}$ & Hydrolytic capacity \\
\hline $\mathrm{CL} 10^{-6}$ & 39 & 7.8 \\
$\mathrm{AL} 10^{-4}$ & 41 & 10.3 \\
$\mathrm{Cb} 10^{-4}$ & 63 & 15.8 \\
$\mathrm{Ca} 10^{-4}$ & 55 & 11.0 \\
$\mathrm{Ab} 10^{-6}$ & 53 & 13.3 \\
$\mathrm{Ca} 10^{-6}$ & 58 & 11.6 \\
\hline
\end{tabular}

KEY:

A $=$ Hotel soluos soil sample

$\mathrm{AL}=$ Hotel soluos leachate sample

$\mathrm{C}=$ Ibeshe soil sample

$\mathrm{CL}=$ Ibeshe leachate sample 
Int.J.Curr.Microbiol.App.Sci (2016) 5(11): 842-853

Fig.1 Pure Culture of Fungal Isolates

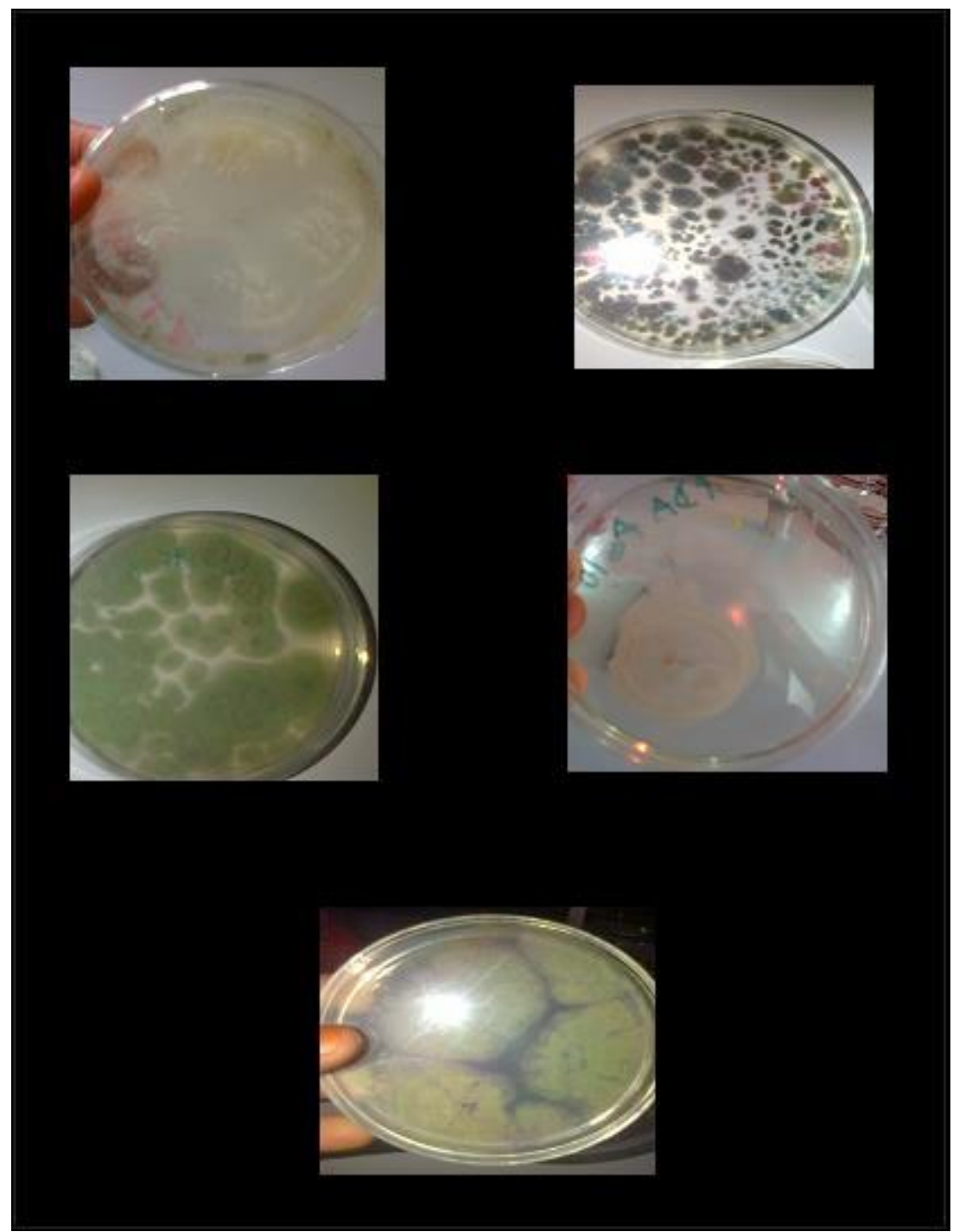


Int.J.Curr.Microbiol.App.Sci (2016) 5(11): 842-853

Fig.2 Bacterial Isolates with cellulase activity

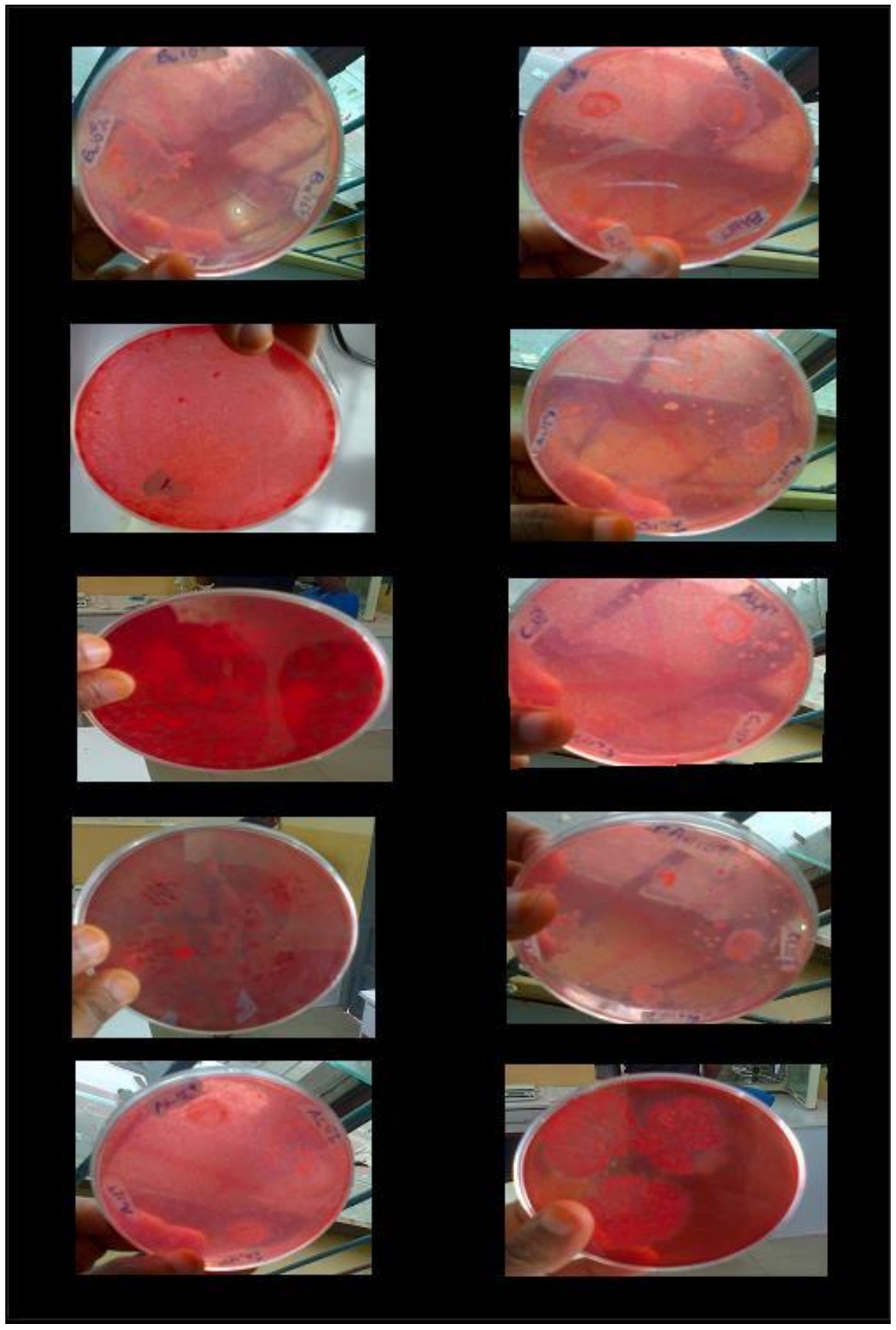


Also, future research would seek to extract the DNA sequence of these cellulolytic microorganisms to develop a DNA probe from that for enhanced environmental surveillance for this group of organisms as well as their integration into waste-toenergy programme.

\section{Acknowledgements}

The authors are grateful to the Chief Technologists in Microbiology and Botany laboratories of LASU; Dr. Ola-Gbadamosi and Mr. Sanni particularly as well as other laboratory staff for their assistance and cooperation.

\section{References}

Abu, E.A., Onyenekwe, P.C., Ameh, D.A., Agbaji, A.S., Ado, S.A. 2000. Cellulase (EC 3.2.1.3) production from sorghum bran by Aspergillus niger SL 1. An assessment of pretreatment methods.In:Proceedings of the International Conference on Biotechnology; Commercialization and food Security, Abuja, Nigeria. p. 153-159.

Ali, S., Sayed, A., Sarker, R.T., Akin, R. 1991. Factors affecting cellulose production by Aspergillus terreus using water hyacinth. World $J$. Microbiol. Biotech., 7: 62-66.

Banjo, N.O., kuboye, A.O. 2000. Comparison of the effectiveness of some Agro-industrial wastes in growing three tropical edible mushrooms (Volvarellavolvacea, Pleurotuspulmonaris,

Lentimussquarrosulus).

In:

preceedings of the International

Conference on Biotechnology

Commercialization and Food Security,

Abuja, Nigeria p. 161-165.

Beg, Q.K., Gupta, R. 2003. Purification and characterization of an oxidation stable thiol- dependent serine alkaline protease from Bacillus mojavensis. Enzyme and Microbial Technol., 32: 294-304.

Chakraborty, N., Sarkar, G.M., Lahiri, S.C. 2000. Cellulose degrading capabilities ofcellulolytic bacteria isolated from the intestinal fluids of the silver cricket. Environmentalist, 20: 9-11.

Cheesbrough, M. 2006. District Laboratory Practice in Tropical countries (2nd edition) London English p.25-45.

Das, A., Bhattacharya, S., Murali, L. 2010. Production of cellulase from a thermophilic Bacillus sp. Iso;ated from cow dung. American Eurasian J. Agric. Environ. Sci., 8(6): 685- 691.

Gautam, S.P., Bundela, P.S., Pandey, A.K., Awasthi, M.K., Sarsaiya, S. 2009. Prevalence of fungi in municipal solid waste of Jabalpur city (M.P). J. Basic and Applied Mycol., 8(3): 80-81.

Gautam, S.P., Bundela, P.S., Pandley, Jamaluddin, Awasthi, M.K., Sarsaiya, S. 2010. Cellulase production by Pseudomonas sp. Isolated from municipal solid waste compost. Int. J. Academic Res., 2(6):330-333.

Gautam, S.P., Bundela, P.S., Pandey, A.K., Jamaluddin, Awasthi, M.K., Sarsaiya, S. 2012. Diversity of cellulolytic microbes and the biodegradation of municipal solid waste by a potential strain. Int. J. Microbiol., 12p. (doi: 10.1155/2012/325907).

Holt, J.G. 1994. The aerobic endosporesforming rods and cocci. In:Bergey's manual of determinative bacteriology, (9th ed.)Ed.Holt JG., Williams and Wilkins, Baltimore, MD. 670-675.

Kang, S.W., Ko, E.H., Lee, J.S., Kim, S.W. 1999. Over production of $\beta$ glucosidase by Aspergillusniger mutant from lignocellulosic biomass. Biotech. Lett., 21: 647-650. 
Levy, I., Shani, Z., Shoseyov, O. 2002. Modification of polysaccharide and plant cell wall by endo-1, 4-bglucanase and cellulose-binding domains. Biomolecular Engi., 19:1730.

Lu, W.J., Wang, H.T., Yang, S.J., Wang, Z.C., Nie, Y.F. 2005. Isolation and characterization of mesophilic cellulose degrading bacteria from flower stalks -vegetable waste cocomposting system. J. Gen. and Applied Microbiol., 51: 353-360.

Nakamura, K., Kitamura, K. 1988. Cellulases of Cellulomonasuda. Methods in Enzymol., 160: 468-472.

Narasimah, G., Sridevi, A., Buddolla, V., Subhosh, C.M., Rajasekhar, R.B. 2006. Nutrient effects on production of celluloytic enzymes by Aspergillus niger. African J. Biotechnol., 53: 375380.

Obire, O., Nwaubeta, O., Adue, S.B.N.
2002. Microbial community of a waste dumpsite. J. Appl. Sci. Environ. Management, 6(1): 78-83.

Oyeleke, S.B., Oduwole, A.A. 2009. Production of amylase by bacteria isolated from a cassava waste dumpsite in Minna, Niger State, Nigeria. African J. Microbiol. Res., 3(4): 143-146.

Rani, D.S., Nand, K. 2000. Production of thermostable cellulase - free xylanase by Clostridiumabsonum CFR -702. Process Biochem., 36(4): 355-362.

Ryu, D.D., Mandels, M. 1980. Cellulase: Biosynthesis and Applications. Enzyme Microbiol. Technol., 2: 92102.

Van, J.P., Mohulatsi, M. 2003. Biodegradation of waste paper by cellulose from Trichoderma viride. Biores. Technol., 86: 21-23.

\section{How to cite this article:}

Ojo-Omoniyi, OlusolaAbayomi, Okwa, Omolade Olayinka, Junaid, Iswat Olaide and Ikuoye, Abosede Oyebola. 2016. Sustainable Solid Waste Management: Isolation of Cellulolytic Microorganisms from Dumpsites in Lagos, Southwest Nigeria. Int.J.Curr.Microbiol.App.Sci. 5(11): 842-853. doi: http://dx.doi.org/10.20546/ijcmas.2016.511.096 